\title{
Correlation Between Socio-Economic Consequences and the External Effects Management of Regional Medical Systems
}

\author{
Shvets Yuri Yurievich ${ }^{1^{*}}$
}

\author{
${ }^{1}$ Institute of control of science V.A. Trapeznikov of RAS \\ Financial University under the Government of the Russian Federation \\ *Corresponding author. Email: jurijswets@yahoo.com
}

\begin{abstract}
The article deals with the questions of social correlation in relation to the content of health protection issues. The generally accepted social contract in the sphere of health protection turned out to be broken by the events that took place in the world at the beginning of 2020. Principles of mutual assistance and built regional models of health care turned out to be incapable and hope for them is false. The challenge for regions faces the task of rebuilding their own health principles without orienting themselves towards anyone to ensure the future security of populations from such threats.
\end{abstract}

Keywords: health system, social interaction, health care, evaluation system.

\section{INTRODUCTION}

Today, the global situation has been significantly complicated by the presence of an epidemic and a pandemic regarding the COVID-19 virus detected at the end of 2019. The panic that exists in the population is related to the lack of sufficient information for citizens about the possibilities and dates of ending their "isolation" from everyday life and the threat to their lives.

The current epidemic situation regarding the coronavirus demonstrates that new outbreaks of human viral infections will continue to be relevant to global public health issues. The overall epidemic risk of these outbreaks will depend on the appropriate characteristics of the virus, the time of its spread among humans, the severity of the emerging disease and other measures available to contain and control the epidemic situation.

By the end of March 2020, there are many questions about the new virus, as well as its modes of transmission, natural reservoir and pandemic capacity. In this regard, it should be assumed that the COVID-19 outbreak is not the last one, unless proven antiviral medicines and coronavirus vaccines are developed, the available knowledge about their epidemiology is limited.

We can say that a possible new factor in the epidemic outbreaks will be the increase in population, increased contacts between wildlife and humans, the mastering of new technologies by humans, and improved transport communication between individual states. Based on the fairly rapid spread of this infection, a significant number of infected citizens, an increased baseline for the reproduction of infection, it is worth asserting that COVID-19 is more dangerous than other outbreaks of coronavirus pneumonia.
The increased threat of rapid and global spread of COVID19 as a new virus is already recognized by WHO. In the absence of specific therapy, measures of sanitaryquarantine supervision and prevention, reporting on cases of infection and early diagnosis, active supportive therapy for all diseases, timely informing citizens about the epidemic situation and possible preventive measures against coronavirus diseases are very important.

\subsection{Related Work}

Clinical researches and development of therapeutic and prophylactic medicines against coronaviruses today give hope for formation of an effective means for control and struggle against coronavirus infections, including COVID19 [9].

The events of the beginning of 2020 associated with the spread of COVID-19 showed fragmentation of management approaches in regulating the epidemiological stability of countries and territories. The 21 st century showed the world such challenges as SARC/TORS, H5N1, N1H1, MERS, Ebola [1]. Despite the dominant informational role of $\mathrm{WHO}$ in the necessity of evaluating the threat and implementing preventive measures to avoid the development of such threats [2], at some point in time, all of the organization's actions are insufficient and belated, which is one of the reasons for the declared pandemic.

Inconsistent action, in turn, causes the virus to spread between regions, which is less important for this study than how different regions act differently to overcome it. Regional effectiveness can be judged by examining mortality rates depending on the actions used to prevent a threat [3]. 
The classical management approach requires to act maximizing one's own benefit and globally it should lead to general well-being, but adding to it the principle of "laissez faire" as a generally accepted principle in the EU which is absolutely incompatible with the desire to combine social and economic approach to health protection, which can be observed right now.

It is quite possible that such logic is declared both in Adam Smith's time and today, and some countries adhere to this idea (for example, France and Germany), but in this case declared values and freedoms are replaced by regional necessity, which is forgotten for the society and can be perceived in various, different layers of the population (an example can be seen in actions in Ukraine [4]).

Assuming that the goal which is set for the regions at risk is the same, it can be concluded that the decisions should be the same. Unfortunately, we can see the absolutely opposite picture. Countries that even belong to different governmental organizations operate differently [6].

It can be assumed that they are driven by a certain interest which in theory is called "medial choice" associated with a different share of benefits and consequences from the actions of the government in a different time period depending on the proximity or remoteness of the choice (as in Israel, which survived the third election in six months, the United States, where the election is expected in six months, Russia, which will postpone voting on changes to the Constitution), or a high share of social absolutism as in China. These countries were the first ones to introduce the most stringent quarantine requirements, without waiting for the disease to grow exponentially.

The opposite example can be seen in such countries as Ukraine, Italy, presidential elections in April 2019, parliamentary elections in Italy and Germany in 2018 and 2017 respectively, not mentioning the elections to the EU Parliament in 2019. These countries and their executive bodies have been inactive until the last moment and are inactive today (the refusal of Germany, France and Austria to send their doctors to help Italy).

In such an aspect it is impossible to speak about the social component in the context of health care development, and therefore the thesis about European unity collapses and the thesis "laissez faire" is most acutely demonstrated [7]. Transferring this principle to interregional development it can be assumed that its aim is the survival of the strongest, which again is not consistent with the principles within the European cooperation and good neighbourhood.

And in this aspect, it is necessary to move away from the understanding of threats from purely medical in terms of calculating the potential threat and the principles of combating it, and translate them into concepts of territorial development opportunities for territories that can assess the benefits of adopting an initiative to address potential problems. In the context of WHO tasks it is possible to say that local health services of the selected countries cope better and faster than the organization itself (for example, construction of a hospital in Wuhan, local and widespread disinfection, checking (controllers) on the way out of the house, early development of the system of diagnostics of the given disease in Russia and, of course, lack of medical masks, or their export despite the ban.

It is possible to speak that superstructure of new, control system which will allow to build new arrangements in the game theory connected with a dilemma of the prisoner and to build new balance on Pareto which for today is destroyed is necessary. For today, there are no effective associations in this direction.

Supranational unions, such as BRICS, EAEC, SCO, set a goal of joint social and economic development of the countries, implying economic and information security of the countries that are members of these unions, but missing the joint regulation of health care system as part of both social and economic security of the countries, which is an omission and window of opportunity for further development of these unions. Inclusion of such principles in the formula of these associations will significantly increase the prestige of these associations in the international arena, and we are likely to see such associations on the basis of the treaties on mutual cooperation in North America and Western Europe.

Although, for the time being, there are some mutual claims between these countries, the BRICS countries have a chance to move forward in this direction. The above mentioned window of opportunity not only reduces the risk of purely medical nature, but also increases the scientific and methodological potential of the countries. These are new jobs, specialization for companies producing high-tech equipment.

And of course, the search for new principles of social correlation, especially when Italy instead of aid from neighbouring EU countries accepts various help from China, Cuba and Russia. Here it is necessary to remember the events of 1986, when after the Chernobyl disaster Fidel Castro decided to accept the free admission of children from the USSR affected by the explosion (Children of Chernobyl Program), one of the consequences of this reaction was the cancellation of 31.7 billion U.S. dollars in debt to Cuba in 2014 by Russia [8].

The systematic data available today on COVID-19 caused by infections can greatly assist in making optimal decisions regarding therapy choices. It is recommended to be guided by the present national recommendations and the main recommendations of $\mathrm{WHO}$ in the treatment and prevention of coronavirus infection and its complications [10].

The Russian authorities continue to report few cases of infection with the virus today, but health care professionals are taking emergency measures in case of a mass epidemic in Russia, including the closure of most enterprises, schools, nursery schools and other organizations.

Specialists are trying to find out whether Russian medicine is ready for a real epidemic, which Italy could not cope with. However it is necessary to distinguish separate situations in the field of quantity of the diseased in Korea and Italy, Russia. Having missed the first patient in Korea, but soon began a large-scale testing, the authorities of the country took care to stop the significant spread of the virus COVID-19. In this country all citizens are tested in a 
timely manner, the minimum level of lethality is about $0.4-$ $0.5 \%$.

The situation in Italy is completely different. In this country, there has been a significant "import" of the virus, so the situation is worth assessing not only hard, the possibility of stopping the spread of the virus was missed. In Russia, of course, the situation is different. The authorities in Russia reacted quite quickly, all border regions quickly began to close, people are actively being isolated to prevent the spread of COVID-19. In Russia, the so-called centralized sanitary-epidemiological control service has been preserved, which worked quite clearly. In addition, the country has developed its own tests with results within 3-4 hours and mass production has been established.

\section{BACKGROUND}

In the near future, specialists will move from testing people with symptoms to those who have mild ailments, then absolutely anyone can be tested. This measure will help identify patients in whom the infection is asymptomatic at all. According to experts from WHO, Russia was ready for coronavirus much better than many countries, because Russia has developed significant experience in combating complex forms of pneumonia, as well as resistant forms of various lung diseases.

The problem is that the population of the country does not believe in the health care system at all. Anyway, Russia has always been native to numerous infectious diseases, it is simply "unfair" not to trust the domestic anti-epidemic system.

Another problem is that some part of the population believes that responsibility before the state is lower than their personal freedom. Due to this attitude of the European citizens, the epidemic is currently higher than in China. Russia lacks optimal stock management of masks and disinfectants. When summing up the results of the fight against COVID-19, we do not expect the scenario of Italy, but we can say that the country lacks the necessary equipment and materials, as well as pulmonary ventilators. A rather vulnerable point in our health care is that no one can constructively conduct a dialogue with the population. Here, the Ministry of Health should understand that at the moment the situation is developing mainly by the laws of social psychology. As the epidemic grows, the health care system may face significant difficulties [11]. The main reason for this is the underfunding of medical facilities, as well as the reduction of the network of inpatient facilities, infectious beds and departments, which was done earlier for rational use of funds.

The Russian health care system cannot cope with the coronavirus not only because the main departments and technological areas of vaccine development are not sufficiently prepared. The present system self-regulates so that in optimum life works in the best rhythm, in crisis conditions - does not cope with the influx of disease.

Probably, it is connected with reduction of out-of-limit cost of health care, decrease in quantity of equipment in some regions of the country. So far, scientists have formed an international map of the virus's spread. Specialists are actively claiming that the virus is evolving, each country has its own indicators of its spread. Russia is not yet particularly represented on the virus tracker, because it has not yet sent a dedicated virus to the international database sequences. There are not many Russian publications on the issue.

The majority of mutations of coronaviruses are more or less neutral, however, no significant work has been done yet to compare the frequency of occurrence of virus strains in heavy and light patients. Over the past 25 years, the health care system in the Russian Federation and the science of this area as a whole have developed in such a way as to make it as difficult as possible for different kinds of users to access individual personal information.

The Russian population has a stable expression - to strengthen immunity. However, it is developed differently for everyone. Some quite quickly and easily cope with viruses, while others have a long way to go in dealing with bacteria. At present, there is no obvious and active epidemic; accordingly, it is important to counterproductively form all decisions aimed at protecting citizens and treating infected patients [12].

Scientists cite the speed at which decisive measures are taken as the reason for the success of Russian public health in combating the pandemic. Restrictions on exit and entry from the country significantly reduce the level of the virus spread outside certain areas, and the quarantine conditions introduced also help to slowly eliminate the pandemic.

The separate interest of scientists and health care workers is closely aimed at improving the quality of medical care to citizens in more remote regions. This is caused by their insufficient financing and the lack of a sufficient number of medical facilities and hospitals.

While COVID-19 is spreading around the world, physicians and authorities are trying to avoid a significant and dramatic increase in the number of cases. "Levelling the curve" or "levelling the peak" is a vital necessity, it is important to avoid a general reset of the national health care system and to reduce the mortality rate. The general elimination of this epidemic curve is possible through organizational measures and control of infection transmission, stabilization of the load on the Russian health care system.

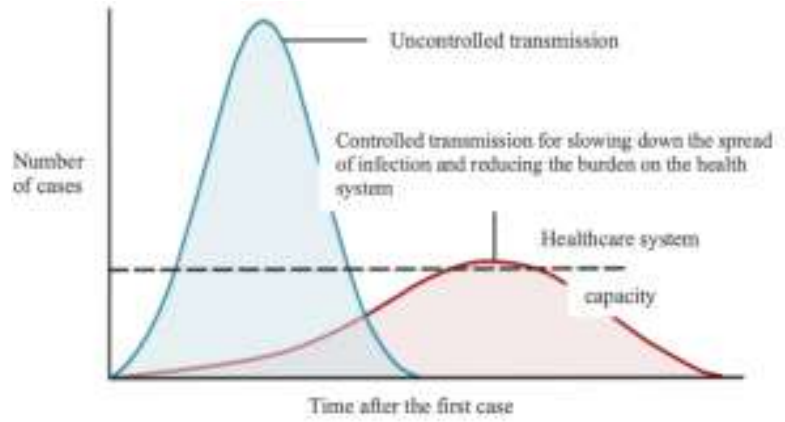

Figure 1 Conditions for the "flattening" of the epidemic curve 
Here you can see examples of acute peak and flat curve, which far exceed the capabilities of the domestic health care system. In general, there is a significant discrepancy in the degree of preparedness for the influx of infected people in some regions. Combating the spread of the virus in individual regions is primarily aimed at reducing the cumulative number of cases, but it is worth slowing down the rate of their overall increase.

\section{CONCLUSION}

The acute peak in the figure is the most "nightmarish" scenario. The Russian health care system in the most under-protected regions will not be able to cope, and as a result the quality of medical care provided to all patients will suffer. In many areas more distant from the centres, there is a significant lack of beds, an increased burden on doctors and, in general, a lack of staff. This acute peak will lead to an increase in mortality, as not all patients receive all the necessary assistance, or receive it late [13].

The problems that are currently observed in the health care system against the background of social correlation are:

- insufficient number of personnel in medical institutions in some regions;

- lack of sufficient number of hospitals and medical institutions in more remote regions;

- insufficient number of medicines and related protective equipment;

- panic among the population due to the pandemic;

- insufficient hygienic measures taken;

- lack of success of the "social contract";

- insufficient coordination of Russian efforts with individual countries.

Reducing the impact on people is required to align the curve in the regions. The authorities certainly cannot ban people from leaving their homes and allocate excessive funding. All this requires costs and coordinated action. Of course, numerous data today indicate that the epidemic itself is slowly declining in China, over time it should happen in other countries with optimal action by WHO staff and authorities. At the same time, all must contribute to the recovery of themselves and their loved ones in a timely manner.

According to specialists and representatives of the World Health Organization, the Russian health care system as a whole is ready to fight the coronavirus, but it is important for citizens to follow the rules and stay at home during quarantine, otherwise, the number of cases of infection will increase significantly in both central and more remote areas. It has been noted that it is important that Russians generally observe the various hygienic measures taken [14].

In the nearest future, the Russian health care system will have to face various manifestations of the epidemic, however, specialists and medical workers are still working to curb the spread of the virus, eliminate the already formed panic in the country's citizens, and provide timely treatment to infected patients.
The previously adopted so-called social contract for the protection of public health is not effective enough with regard to the events that are developing in March 2020. All the principles of mutual assistance that have been adopted by the regional models of health care have indeed proved to be ineffective. Today, many regions of the Russian Federation face the task of actively forming principles with a focus on general prevention of the spread of the epidemic.

\section{REFERENCES}

[1] World Health Organization, challenges of the 21st century. Electronic resource: https://www.who.int/csr/disease/ebola/ebola-6months/myths/ru/ (access date 20.03.2020).

[2] WHO Goal and Targets. Medical Internet Conferences. Electronic resource: https://medconfer.com/node/18043 (access date 20.03.2020).

[3] Record mortality in Italy, decline of the disease in China. TNS. Electronic resource: https://tsn.ua/ru/svit/rekordnaya-smertnost-v-italii-ispad-zabolevaemosti-v-kitae-kak-mir-perezhil-20marta-vo-vremya-pandemii-koronavirusa-1511835.html (access date 22.03.2020).

[4] Ukraine has the highest mortality rate from COVID19, but least tests. Zn.ua. Electronic resource: https://rg.ru/2020/03/20/na-ukraine-samaia-vysokaiasmertnost-ot-covid-19-no-menshe-vsego-testov.html (access date 20.03.2020).

[5] Blekhcin I.J. the Strategy of sustainable development of regional systems. SPb.: IRE RAS publishing house, 2001. $13 \mathrm{p}$.

[6] Coronovirus Covid 19. Monitoring. Vadamer. Electronic resource: https://vademec.ru/news/2020/02/04/koronavirus-2019ncov-monitoring/ (access date 23.03.2020).

[7] Kuttner, Robert. "Globalization and Its Critics". The American Prospect. Retrieved 17 March2019. Electronic resource: access mode https://prospect.org/features/globalization-critics/ (access date 01.03.2020).

[8] Putin wrote off a $\$ 32$ billion debt to Cuba. Forbes.ru. Electronic resource: https://www.forbes.ru/news/262397-putin-spisal-90dolgov-kuby-pered-sssr-na-32-mlrd (access date 01.03.2020). 
[9] Gorenkov D.V. Khantimirova L. M. Shevtsov V. A. Rukavishnikov A. V. Merkulov A. V. Olefir Yu. V. The outbreak of a new infectious disease COVID-19 as a threat to global health // Biopreparations, prevention, diagnosis, treatment, №1, 2020. 6-20 p.;

[10] Romanov B.K. Coronavirus infection COVID-19// Safety and risk of pharmacotherapy, № 1, 2020. 3-8 p.;

[11] Will Russian medicine cope with the peak of coronavirus epidemic? https://meduza.io/feature/2020/03/18/vyderzhit-lirossiyskaya-sistema-zdravoohraneniya-kogdaepidemiya-koronavirusa-dostignet-pika-vot-dva-otvetaoptimistichnyy-i-ne-ochen (access date 30.03.2020);

[12] Why is the world not ready for coronavirus and how will the disease change everything around? https://lenta.ru/articles/2020/03/26/genetik/ (access date 30.03.2020);

[13] The coronavirus epidemic cannot be stopped yet, but it can be slowed down. Why is it important to strive for it? https://www.bbc.com/russian/features-51834576 (access date 30.03.2020);

[14] WHO assessed the readiness of the Russian health system to fight COVID-19

https://russian.rt.com/russia/news/732684-voz-

zdravoohranenie-rossiya-koronavirus (access date 30.03.2020). 